\title{
Generating Plants with Improved Water Use Efficiency
}

\author{
Sonja Blankenagel ${ }^{1}$, Zhenyu Yang ${ }^{2, *}$, Viktoriya Avramova ${ }^{1} \mathbb{B}$, Chris-Carolin Schön ${ }^{1}$ \\ and Erwin Grill ${ }^{2}$ \\ 1 Plant Breeding, School of Life Sciences Weihenstephan, Technical University of Munich, \\ Liesel-Beckmann-Straße 2, 85354 Freising, Germany; sonja.blankenagel@tum.de (S.B.); \\ viktoriya.avramova@tum.de (V.A.); chris.schoen@tum.de (C.-C.S.) \\ 2 Botany, School of Life Sciences Weihenstephan, Technical University of Munich, Emil-Ramann-Straße 4, \\ 85354 Freising, Germany; erwin.grill@wzw.tum.de \\ * Correspondence: zyang@wzw.tum.de; Tel.: +49-(8161)-71-5426
}

Received: 13 August 2018; Accepted: 14 September 2018; Published: 18 September 2018

\begin{abstract}
To improve sustainability of agriculture, high yielding crop varieties with improved water use efficiency (WUE) are needed. Despite the feasibility of assessing WUE using different measurement techniques, breeding for WUE and high yield is a major challenge. Factors influencing the trait under field conditions are complex, including different scenarios of water availability. Plants with $C_{3}$ photosynthesis are able to moderately increase WUE by restricting transpiration, resulting in higher intrinsic WUE ( $i$ WUE) at the leaf level. However, reduced $\mathrm{CO}_{2}$ uptake negatively influences photosynthesis and possibly growth and yield as well. The negative correlation of growth and WUE could be partly disconnected in model plant species with implications for crops. In this paper, we discuss recent insights obtained for Arabidopsis thaliana (L.) and the potential to translate the findings to $\mathrm{C}_{3}$ and $\mathrm{C}_{4}$ crops. Our data on Zea mays (L.) lines subjected to progressive drought show that there is potential for improvements in WUE of the maize line B73 at the whole plant level (WUE $\left.\mathrm{plant}_{\mathrm{t}}\right)$. However, changes in $i \mathrm{WUE}$ of $\mathrm{B} 73$ and Arabidopsis reduced the assimilation rate relatively more in maize. The trade-off observed in the $\mathrm{C}_{4}$ crop possibly limits the effectiveness of approaches aimed at improving $i \mathrm{WUE}$ but not necessarily efforts to improve WUE $\mathrm{plant}_{\text {. }}$
\end{abstract}

Keywords: water use efficiency; crop breeding; yield; drought; maize; Arabidopsis; $\mathrm{C}_{4}-\mathrm{C}_{3}$ comparison; stomatal conductance; abscisic acid (ABA); photosynthesis

\section{Introduction}

Green Revolution technologies and significant expansion in the use of land, water, and other natural resources for agricultural purposes have led to a tripling in agricultural production between 1960 and 2015 [1]. Despite this success, the high costs to the natural environment that accompany elevated productivity and changes in the food supply chain threaten the sustainability of food production [1]. Global food security is further challenged by climate change, with a predicted increase in frequency of droughts [2,3]. Globally, agriculture accounts for at least $70 \%$ of withdrawals from freshwater resources, with large effects on ecosystems [4,5]. Despite this high water deployment, major yield losses due to water deficits are experienced in crops [6]. At the same time, global population growth increases the demand for food, feed, and fuel, which intensifies the pressure to improve water use efficiency (WUE) of crops $[7,8]$. While better crop and water management practices provide an immediate opportunity to increase crop water productivity, breeding for superior varieties can achieve a medium- and long-term increase $[9,10]$. 
Physiologically, water use efficiency can be defined at different scales [11-13]. At the plot level, it represents the ratio of grain or biomass yield to water received or evapotranspired. At the single plant level ( $\left(\mathrm{UE}_{\text {plant }}\right)$, it is the ratio of biomass to transpiration. The increase in biomass and amount of water transpired over time can be assessed gravimetrically [14]. However, this is destructive and laborious on a long-term basis, especially regarding large crops like maize and sorghum. Therefore, analyses of intrinsic water use efficiency ( $i$ WUE) and carbon isotope discrimination $\left(\Delta^{13} C\right)$ are used as surrogates when evaluating WUE $[11,15]$. The $i$ WUE is assessed at the leaf level as the ratio of net $\mathrm{CO}_{2}$ assimilation $\left(\mathrm{A}_{\mathrm{n}}\right)$ to stomatal conductance $\left(\mathrm{g}_{\mathrm{s}}\right)$ and can be measured noninvasively with portable gas exchange equipment [16]. As transpiration rate (E) is influenced not only by $\mathrm{g}_{\mathrm{s}}$ but also by the leaf-to-air vapor pressure deficit (VPD) of the air [17], iWUE usually differs from transpiration efficiency $\left(\mathrm{A}_{\mathrm{n}} / \mathrm{E}\right)$. In addition, VPD affects the stomatal aperture and therefore $\mathrm{g}_{\mathrm{s}}[17,18]$. Extrapolation of gas exchange data from single-leaf to whole plant is error-prone due to differences in photosynthesis and transpiration among leaves [19]. Prediction of long-term biomass accumulation and water consumption, WUE $E_{\text {plant }}$, based on $i$ WUE is even more uncertain given the possible differences in VPD and additional physiological processes such as dark respiration and photorespiration influencing the resulting biomass increase [19]. Despite these limitations, analysis of $i$ WUE provides a convenient measure for the water efficiency of carbon capture. The throughput of $i$ WUE analyses is quite low as only single, time-consuming measurements per plant can be taken, which impedes large-scale phenotyping.

Analysis of stable carbon isotope discrimination $\left(\Delta^{13} C\right)$ offers a suitable alternative in $C_{3}$ plants by providing a read-out for transpiration efficiency integrated over time. Discrimination of the heavier isotope is mainly caused by differences in diffusion rates of the isotopes and enzymatic discrimination during carboxylation reactions [20]. Therefore, $\Delta^{13} \mathrm{C}$ has been used as an indirect trait to select cultivars with improved WUE [21-24]. By combining the analysis with oxygen isotope enrichment $\Delta^{18} \mathrm{O}$, an estimation for transpiration rate [25-27], contributions of water loss, and $\mathrm{CO}_{2}$ assimilation on $i$ WUE could be disentangled [28-30]. Stable isotope compositions of leaves or grains, however, represent integrated measures of many processes over a period of plant growth and therefore correlation with $i$ WUE can be limited [31]. In $\mathrm{C}_{4}$ plants, $\mathrm{CO}_{2}$ prefixation, for instance, by phosphoenolpyruvat carboxylase and bundle sheath leakiness restrict the responsiveness of $\Delta^{13} \mathrm{C}$ to changes in WUE [20,32] and make the relationship between $\Delta{ }^{13} \mathrm{C}$, $\mathrm{g}_{\mathrm{s}}$ and WUE in $\mathrm{C}_{4}$ species less predictable compared to $\mathrm{C}_{3}$ plants [13].

Improving WUE of crops is considered beneficial in very dry climates and in very severe and terminal drought conditions, while growth maintenance traits are advantageous under milder drought conditions [33-35]. For crops experiencing water deficit early in their development, traits found to be positive for improving WUE are negative for yield [36]. Enhanced water uptake through investments in the root system can result in reduced plant size and water expenditure for growth maintenance can result in increased drought stress experiences if plants are growing at very low soil water availability $[33,34,36,37]$. Hence, water-conserving traits as imposed by higher WUE would be beneficial, provided growth and yield are not negatively affected.

\section{Disconnecting Improved WUE and Growth Trade-Offs}

Being a ratio, $i$ WUE can be improved by reducing gs per amount of $\mathrm{CO}_{2}$ assimilated or by enhancing the assimilation rate at a given $\mathrm{g}_{\mathrm{s}}$. Both cases result in lowered intercellular $\mathrm{CO}_{2}$ concentration $\left(\mathrm{C}_{\mathrm{i}}\right)$ and consequently in an increased stomatal $\mathrm{CO}_{2}$ gradient $\left(\mathrm{C}_{\mathrm{a}}-\mathrm{C}_{\mathrm{i}}\right.$, with external $\mathrm{CO}_{2}$ concentration $\mathrm{C}_{\mathrm{a}}$ ), which is directly proportional to the ratio of $A_{n}$ to $g_{s}$ according to Fick's law applied to carbon assimilation in leaves, $A_{n}=g_{s}\left(C_{a}-C_{i}\right)[16,38,39]$. Increased $i$ WUE has been observed in several $C_{3}$ species under water deficit conditions when plants reduce $g_{s}[11,15,40-42]$, although a decrease in $g_{s}$ caused by drought was found to be overridden by heat stress [43]. However, closing stomatal pores to reduce transpiration often results in a reduction of $A_{n}[41,44]$. Lowering $g_{s}$ impinges on $C_{i}$ and unless this change in $C_{i}$ is counteracted by an elevated mesophyll conductance 
$\left(\mathrm{g}_{\mathrm{m}}\right)$, the $\mathrm{CO}_{2}$ concentration at the site of Rubisco-dependent carboxylation $\left(\mathrm{C}_{\mathrm{c}}, \mathrm{CO}_{2}\right.$ concentration in chloroplasts) will be reduced $[39,45,46]$. A reduction of $\mathrm{C}_{\mathrm{c}}$ affects the carboxylation efficiency of Rubisco and favors photorespiration $[47,48]$. Sustaining net photosynthesis under these conditions might require a higher electron transfer rate (ETR) and/or reduced nonphotochemical quenching to support enhanced carboxylation by Rubisco for compensation of enhanced photorespiration [49-52]. There are reports that water deficit results in increased $g_{m}$; however, in most analyses, no change or a reduced $g_{m}$ was observed under drought [44,53-58].

Gains in WUE are often associated with growth trade-offs [59,60]. As pointed out by Blum [61], crops with high $\mathrm{CO}_{2}$ assimilation and high biomass accumulation per unit land area require high stomatal conductance. This is supported by the observation of a constant WUE on the field level over a broad range of yields [8]. Nevertheless, there might be ways to achieve elevated WUE and high photosynthesis, namely by exploring $\mathrm{CO}_{2}$ concentrating mechanisms, increased $\mathrm{g}_{\mathrm{m}}$, and increased $\mathrm{CO}_{2}$ specificity of Rubisco [10].

Interestingly, several reports of $C_{3}$ plants have shown enhanced $i$ WUE without the expected negative impact on $A_{n}$ or growth [11,15,62-64], as postulated by plant physiologists [4]. In these studies with transgenic tomato and Arabidopsis plants, $g_{s}$ was moderately reduced by enhancing the biosynthesis or the responsiveness to the phytohormone abscisic acid (ABA) or by reducing the size and density of leaf stomata [15,63-65]. Plants overexpressing distinct ABA receptors-termed ABA-Binding Regulatory Component (RCAR)/Pyrabactin Resistance 1-(like) (PYR1/PYL)—caused increases of 40\% in $i$ WUE, integrated WUE based on $\Delta^{13} \mathrm{C}$ of biomass and cellulose fractions, and WUE $\mathrm{plant}_{\text {[15]. Growth }}$ rates and biomass accumulation were not significantly different from wild type [15]. Hence, the ABA receptor lines revealed higher water productivity, i.e., WUE per time, both under well-watered growth conditions and under water deficit. Net carbon assimilation was comparable to the wild type, however, at lowered $\mathrm{C}_{\mathrm{i}}$ levels and without detectable changes in $\mathrm{g}_{\mathrm{m}}$. This report and other studies show that improving WUE is possible without growth trade-offs. The underlying physiological mechanisms are largely unknown and might involve the root system, as grafting experiments have suggested [15], and enzymes of the $\mathrm{C}_{4}$ metabolism, such as PEP carboxylase and its regulatory protein kinase PEPC kinase, which are both upregulated in $\mathrm{C}_{3}$ plants at low $\mathrm{CO}_{2}$ availability [65].

$\mathrm{C}_{4}$ and $\mathrm{C}_{3}$ plants differ in WUE [66-68]. At a given $\mathrm{g}_{\mathrm{s}}, \mathrm{C}_{4}$ plants show higher net carbon assimilation rates and higher WUE [66]. The $\mathrm{CO}_{2}$ concentrating mechanism involving PEP carboxylase results in saturation of $C_{4}$ photosynthesis at relatively low $C_{i}[69,70]$; therefore, lower $g_{s}$ and a steeper $\mathrm{CO}_{2}$ gradient $\left(\mathrm{C}_{\mathrm{a}}-\mathrm{C}_{\mathrm{i}}\right)$ are realized in $\mathrm{C}_{4}$ plants compared to $C_{3}$ plants [66,70]. $C_{3}$ plants have $C_{i}$ values in the range of $300 \pm 60 \mu \mathrm{mol} \mathrm{mol}^{-1}$, while the $C_{i}$ of the $C_{4}$ plants is around $150 \pm 40 \mu \mathrm{mol}$ $\mathrm{mol}^{-1}$ [71-73] at ambient $\mathrm{CO}_{2}$ of $370-400 \mu \mathrm{mol} \mathrm{mol}^{-1}$ in well-watered conditions. Under optimal growth conditions, maize and sorghum with $\mathrm{C}_{4}$ metabolism therefore have higher yields per water transpired than the $C_{3}$ crop wheat [9].

\section{Comparative Analysis of Maize and Arabidopsis}

The question arises as to whether it is possible to transfer the finding of improved iWUE without having the negative impact on growth to crops. The data on $\mathrm{g}_{\mathrm{s}}$-modified tomato plants suggests that it might work for $C_{3}$ plants [63], but the lower $C_{i}$ level of $C_{4}$ plants could preclude such an accomplishment in maize.

To explore the relevance of these findings of uncoupling WUE improvement and yield decreases for the $\mathrm{C}_{4}$ crop maize (Zea mays L.), we analyzed gas exchange data obtained from the maize inbred line B73 and compared them to findings in Arabidopsis. In addition, we analyzed the $\mathrm{WUE}_{\text {plant }}$ of maize lines subjected to drought. B73 is an inbred line that is commonly used in breeding programs, but is known to be drought-sensitive [74]. B73 was included in a progressive drought stress experiment adapted from Yang et al. [15] in which biomass production with a given amount of water was analyzed and $W_{U E} E_{\text {plant }}$ was determined. In this experiment, B73 showed the lowest WUE $E_{\text {plant }}$ (Figure 1a) compared to the maize inbred Mo17 and lines derived from an introgression library described by 
Gresset et al. [75]. In Figure 1, data are shown of the recurrent parent (RP) of the introgression library as well as two introgression lines differing from RP by reduced (IL-05) or elevated kernel $\Delta^{13} \mathrm{C}$ (IL-81) [75]. A significantly reduced $W \mathrm{WE}_{\text {plant }}$ compared with the recurrent parent for IL-05 shows the potential of genetic improvement for this trait. However, the largest difference in $\mathrm{WUE}_{\text {plant }}$ was observed between B73 and Mo17, with an increase of $\sim 27 \%$ (Figure 1a). Our data is in accordance with a previous drought stress experiment conducted on seedlings of maize inbred lines, where Mo17 ranked top in yield per plant [76]. The results indicate genetic variation in the efficiencies of water use among maize lines and a potential for genetic improvement of the $\mathrm{WUE}_{\text {plant }}$ for $\mathrm{B} 73$.

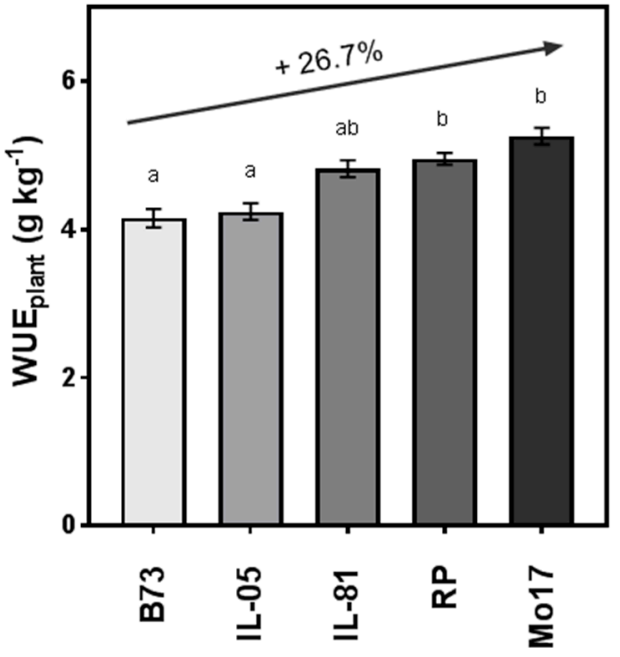

(a)

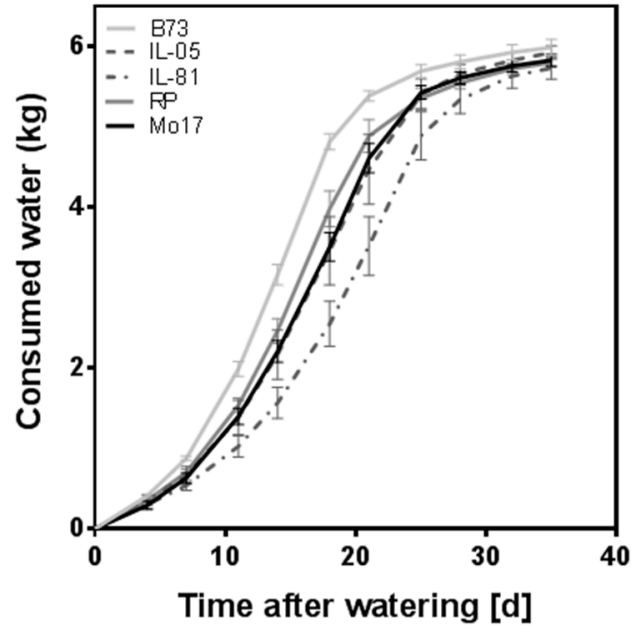

(b)

Figure 1. Water use efficiency and water consumption of maize lines under progressive drought. (a) Water use efficiency (WUE plant $_{\text {) }}$ and (b) whole plant water consumption were assessed over the course of a progressive drought stress experiment adapted from Reference [15]. In the greenhouse, 23 maize genotypes were grown in a randomized complete block design, including the two maize inbred lines Mo17 and B73 and introgression lines described by Gresset et al. [75]. The maize inbred line RP and introgression lines derived therefrom (IL-81, IL-05) were kindly provided KWS Saat SE (Einbeck, Germany). Inbred lines B73 and Mo17 were kindly provided by the Chair of Genetics, Technical University of Munich, Freising, Germany. Prior to the experiment, maize seedlings were established in small pots in the growth chamber $\left(16 \mathrm{~h}\right.$ day at $25^{\circ} \mathrm{C}, 650 \mu \mathrm{E} \mathrm{m}^{-2} \mathrm{~s}^{-1}$ photosynthetically active radiation [PAR], $8 \mathrm{~h}$ night at $20^{\circ} \mathrm{C} ; 75 \%$ relative humidity [RH]) for two weeks after germination under well-watered conditions. Plants of RP harvested at this age had an aboveground dry matter of $0.62 \mathrm{~g} \pm 0.27 \mathrm{~g}$, and plants of an introgression line derived from IL-05 weighed $0.62 \mathrm{~g} \pm 0.26 \mathrm{~g}$. The influence of initial biomass on the biomass at the end of the experiment $(28.74 \mathrm{~g} \pm 2.22 \mathrm{~g}$ and $25.5 \mathrm{~g} \pm 2.39 \mathrm{~g}$, respectively) was approximately $2 \%$. The plants were transplanted into $10 \mathrm{~L}$ pots containing $8 \mathrm{~L}$ water-saturated soil (85\% v/v soil water content; CL ED73, Einheitserdewerke Patzer, Germany, particle diameter $<15 \mathrm{~mm}$ ). A cover of polyethylene foil was used to prevent evaporation, and the progressive drought experiment was initiated by no further watering. The experiment was conducted in the greenhouse (Gewächshauslaborzentrum Dürnast in Freising, Germany) in Oct-Nov 2017 at full sunlight plus supplemental light at $25-33^{\circ} \mathrm{C}, 19-20^{\circ} \mathrm{C}$ day/night, $400 \mu \mathrm{mol} \mathrm{m}{ }^{-2} \mathrm{~s}^{-1} \mathrm{PAR}$, $40 \% \mathrm{RH}$. Soil water content declined progressively during the course of the experiment until the plants used all available water. The water consumed was determined gravimetrically (means \pm SE of $n \geq 4$ biological replicates). WUE $E_{\text {plant }}$ was calculated as final aboveground biomass per water consumed (means \pm SE of $n \geq 4$ biological replicates). The increase in WUE in Mo17 compared to B73 is indicated with an arrow. Student's paired $t$-tests of the maize lines were adjusted for multiple comparisons with the Bonferroni method and lines, which did not differ significantly $(p<0.01)$, and are marked with common letters. 
Maize lines showed a difference in water consumption over the five weeks of the experiment (ANOVA, $p<0.001$, Figure 1b). However, differences in water consumption cannot explain the differences observed in $\mathrm{WUE}_{\text {plant }}$ and towards the end of the progressive drought, all genotypes included in the experiment had consumed an equal amount of water $(5.8 \mathrm{~kg} \pm 0.02 \mathrm{~kg}$, mean $\pm \mathrm{SE})$.

The way in which the change in soil water content (SWC) during the progressive drought experiment affected photosynthesis and $i$ WUE was analyzed by gas exchange measurements. The $A_{n}$ of leaves was fairly constant for maize B73 plants exposed to high SWC levels up to $40 \%$, then the $A_{n}$ dropped steadily approaching zero at approximately $20 \%$ SWC (Figure 2a). In parallel, $\mathrm{g}_{\mathrm{s}}$ changed moderately between $70 \%$ and $40 \%$ SWC and declined to zero at $20 \%$ SWC (Figure $2 \mathrm{~b}$ ). The $\mathrm{C}_{\mathrm{i}}$ values were in the range of $80-100 \mu \mathrm{mol} \mathrm{CO} 2$ per mol between $40-60 \%$ SWC. They were somewhat higher in plants from water-saturated soil and were lowered to a minimum of approximately $40 \mu \mathrm{mol} \mathrm{mol}{ }^{-1}$ at $25 \%$ SWC (Figure 2c). Further reduction of the water content in the soil resulted in the steep rise of $\mathrm{C}_{\mathrm{i}}$ values, indicating collapsing photosynthesis at very low $\mathrm{g}_{\mathrm{s}}$ of plants experiencing severe drought stress. As the ambient $\mathrm{CO}_{2}$ concentration $\left(\mathrm{C}_{\mathrm{a}}\right)$ surrounding the leaf was maintained at $400 \mu \mathrm{mol} \mathrm{mol}^{-1}$, the $\mathrm{CO}_{2}$ gradient $\left(\mathrm{C}_{\mathrm{a}}-\mathrm{C}_{\mathrm{i}}\right)$ at the stomatal pores increased from approximately $250 \mu \mathrm{mol} \mathrm{mol}{ }^{-1}$ $\left(C_{\mathrm{i}}\right.$ of $\left.150 \mu \mathrm{mol} \mathrm{mol}^{-1}\right)$ at soil water saturation to approximately $360 \mu \mathrm{mol} \mathrm{mol}^{-1}\left(C_{\mathrm{i}}\right.$ of $\left.40 \mu \mathrm{mol} \mathrm{mol}^{-1}\right)$ at the brink of terminal drought. The SWC also influenced $i$ WUE (Figure 2d). Values increased from well-watered conditions to a maximum at $25 \% \mathrm{SWC}$, with a plateau around $170 \mu \mathrm{mol} \mathrm{CO} 2$ per mol $\mathrm{H}_{2} \mathrm{O}$ between $40-60 \%$ SWC. Under mild water deficit between $40-60 \% \mathrm{SWC}$, there was little variation in $A_{n}$, and $g_{s}$ and, consequently, the iWUE values.

The results for maize B73 differed from data gained by similar analyses of Arabidopsis plants (Figure 3a-d; Reference [15]). The $A_{n}$ remained constant between 30-70\% SWC, which might be caused by light-limited, but not water-limited, photosynthesis. However, $\mathrm{g}_{\mathrm{s}}$ and $\mathrm{C}_{\mathrm{i}}$ steadily decreased with decreasing SWC and, concomitantly, the iWUE increased by twofold from approximately 35 to $70 \mu \mathrm{mol}$ $\mathrm{mol}^{-1}$ at $30 \%$ SWC. The $\mathrm{CO}_{2}$ gradient at stomata increased more than twofold from approximately $80 \mu \mathrm{mol} \mathrm{mol}^{-1}$ at soil water saturation to approximately $170 \mu \mathrm{mol} \mathrm{mol}{ }^{-1}$ at $30 \%$. The data were obtained at light conditions that did not saturate photosynthesis, but analysis at saturating light confirmed the capacity of Arabidopsis to lower $C_{i}$ and maintain photosynthetic rates unchanged [15]. The improvement in $i$ WUE by limiting $g_{s}$ without major trade-offs in $A_{n}$ (Figure 3) was observed for the $C_{3}$ plants Arabidopsis [15,24] and tomato [63]. A twofold enhancement in iWUE has been reported in different $C_{3}$ species under drought $[11,15,77-79]$. Besides, considerable differences in WUE in the absence of drought stress have been observed among natural variants [80,81]. 


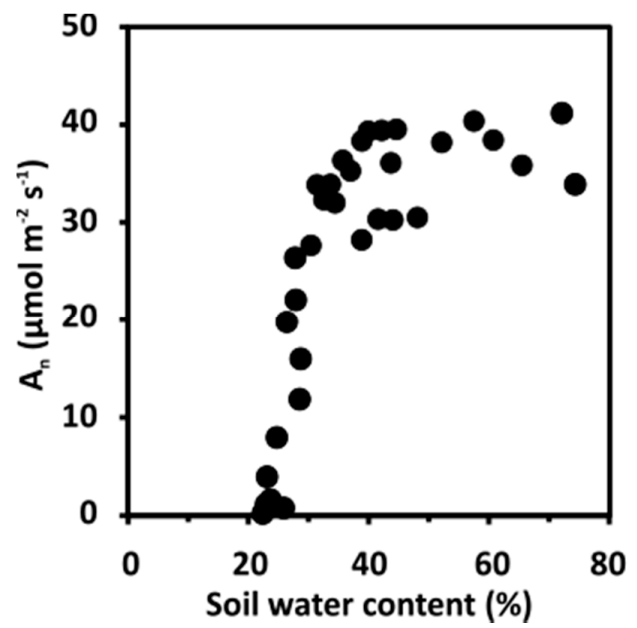

(a)

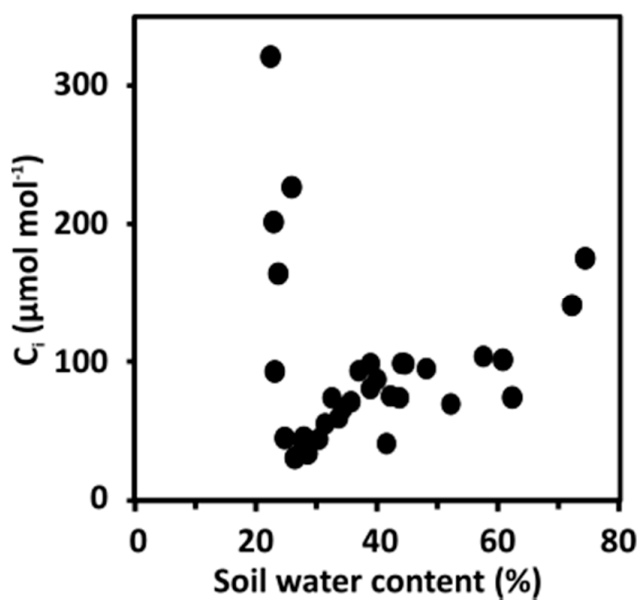

(c)

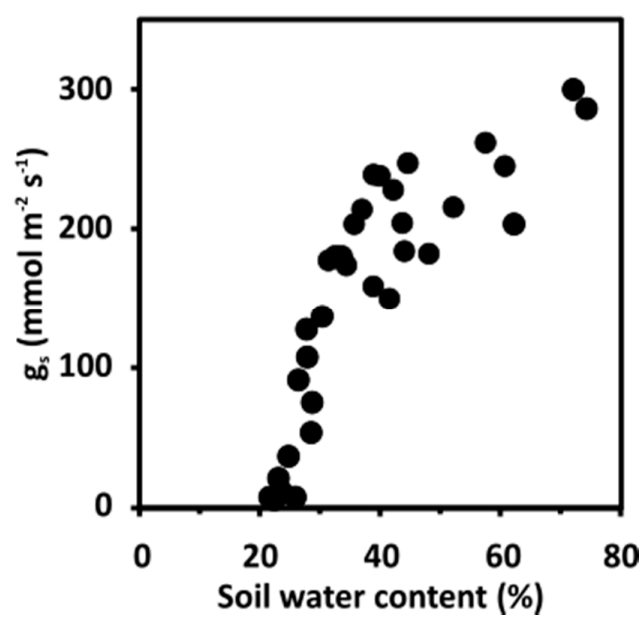

(b)

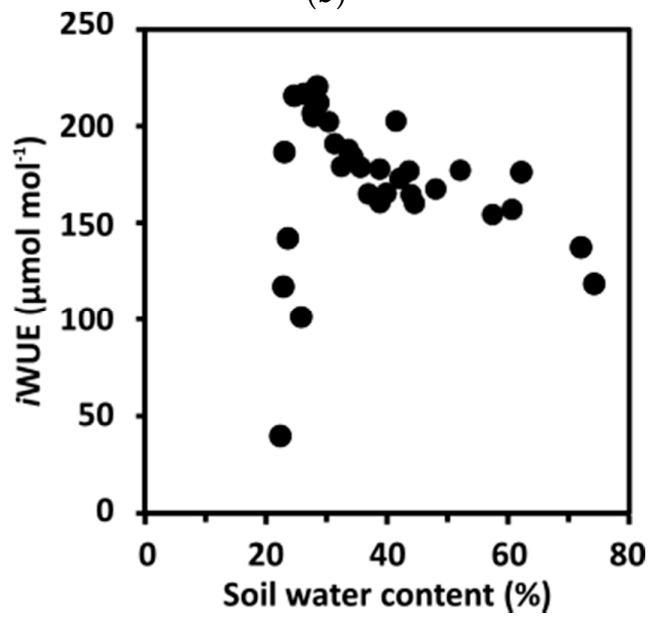

(d)

Figure 2. Changes in intrinsic water use efficiency of maize exposed to a progressive depletion of soil water content. (a) Net carbon assimilation rate $\left(\mathrm{A}_{\mathrm{n}}\right)$, (b) stomatal conductance $\left(\mathrm{g}_{\mathrm{s}}\right)$, (c) intercellular $\mathrm{CO}_{2}$ concentration $\left(C_{i}\right)$, and $(d)$ intrinsic WUE (iWUE; defined as the ratio of $A_{n}$ to $g_{s}$ ) of B73 plants at different soil water content. Gas exchange measurements using the GFS-3000 gas exchange system (Heinz, Walz GmbH, Effeltrich, Germany) were conducted at a photon flux density of $1000 \mu \mathrm{mol} \mathrm{m}{ }^{-2} \mathrm{~s}^{-1}$, an external $\mathrm{CO}_{2}\left(\mathrm{C}_{\mathrm{a}}\right)$ of $400 \mu \mathrm{mol} \mathrm{mol}^{-1} \mathrm{CO}_{2}$, and vapor pressure deficit (VPD) of $26 \mathrm{~Pa} \mathrm{kPa}^{-1} \pm 2 \mathrm{~Pa} \mathrm{kPa}^{-1}$. The first fully expanded leaf counting from the top of the plants was clamped into an $8 \mathrm{~cm}^{2}$ cuvette for measurements, and plants were subjected to progressive drought as detailed in Figure 1. Plants were grown in soil (Classic Profi Substrate Einheitserde Werkverband) as described in Reference [15]. The experiment was conducted in a greenhouse in the Department of Botany in Freising, Germany from June to August. The maize plants were exposed to full sunlight, at an average temperature of $27^{\circ} \mathrm{C}$, and an average relative humidity of $55 \%$ in the experimental period. (a-d) five biological replicates and each data point represents single measurements with five technical replicates. 


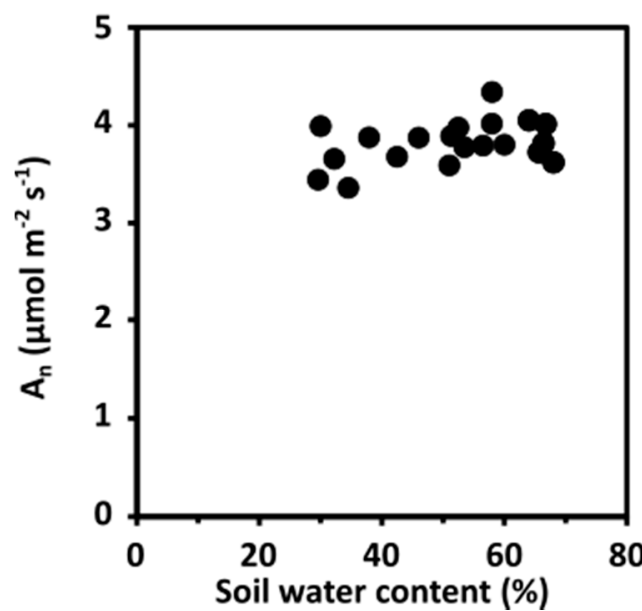

(a)

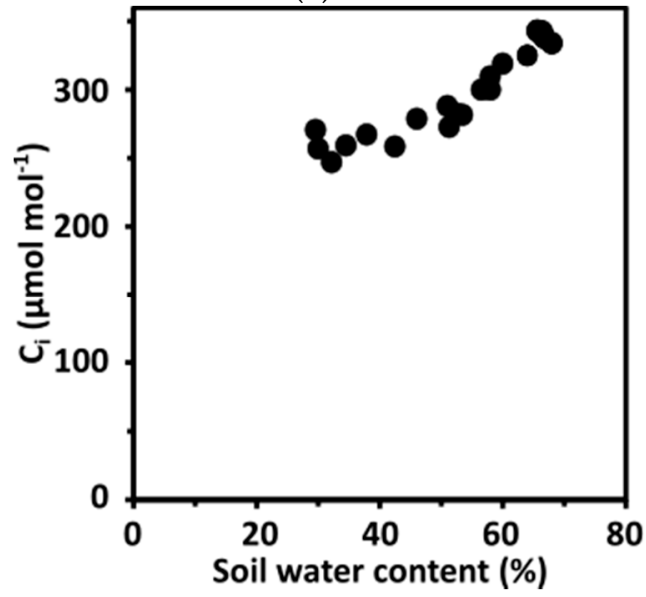

(c)

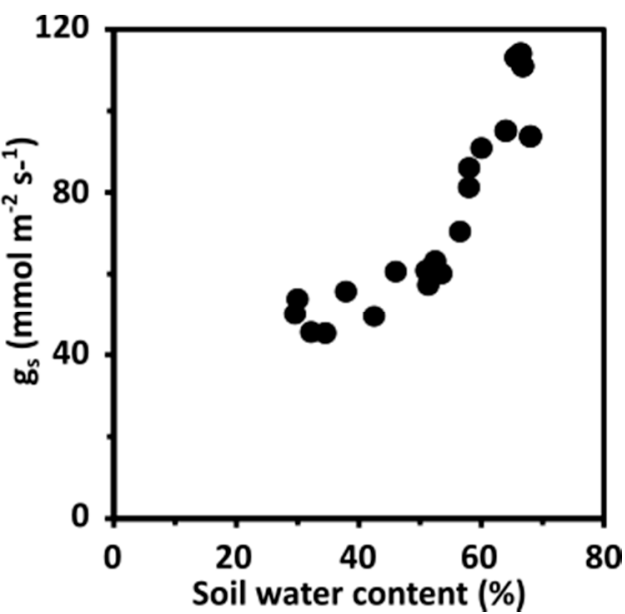

(b)

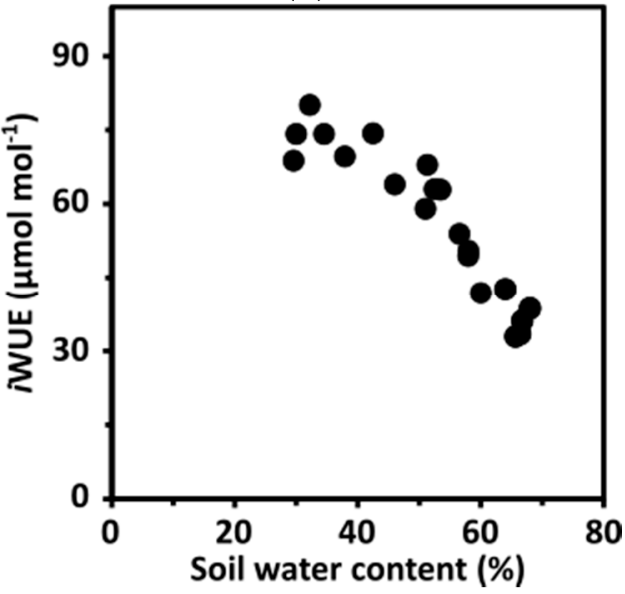

(d)

Figure 3. Changes in intrinsic water use efficiency of Arabidopsis exposed to a progressive depletion of soil water content $(\mathrm{SWC})$. (a) Net carbon assimilation rate $\left(\mathrm{A}_{\mathrm{n}}\right)$, (b) stomatal conductance $\left(\mathrm{g}_{\mathrm{s}}\right)$, (c) $\mathrm{CO}_{2}$ concentration in intercellular space $\left(\mathrm{C}_{\mathrm{i}}\right)$ and $(\mathrm{d})$ intrinsic WUE ( $i$ WUE) of whole leaf rosettes of Arabidopsis accession Columbia (Col-0; kindly provided by the Nottingham Arabidopsis Stock Center, Nottingham, UK). The measurements were performed with the device mentioned in Figure 2 at a photon flux density of $150 \mu \mathrm{mol} \mathrm{m} \mathrm{s}^{-2}$, an ambient $\mathrm{CO}_{2}\left(\mathrm{C}_{\mathrm{a}}\right)$ level of $420 \mu \mathrm{mol} \mathrm{mol}{ }^{-1}$ and vapor pressure deficit of $13 \pm 1 \mathrm{~Pa} \mathrm{kPa}^{-1}$. The plants were grown under short day conditions $(8 \mathrm{~h} \mathrm{light} / 16 \mathrm{~h}$ dark photoperiod) at a photon flux density of $150 \mu \mathrm{mol} \mathrm{m} \mathrm{m}^{-2} \mathrm{~s}^{-1}$ and $22{ }^{\circ} \mathrm{C}$ and $50 \%$ relative humidity in the day time and $17^{\circ} \mathrm{C}$ and $60 \%$ relative humidity at night. Data presented in (a-d) consists of three biological replicates and single measurements for each data point consist of 10 technical replicates. Data and the correlation between SWC and water potentials are presented in Reference [15].

Comparing the results from the analysis of maize and Arabidopsis, the potential for increasing iWUE in maize was more limited relative to Arabidopsis. Between 30-60\% SWC-reflecting mainly mild water deficit [15] - Arabidopsis responded to the mounting water deficit by a 70\% increase in $i$ WUE, while maize showed an increase of less than $20 \%$. Based on the $i$ WUE values obtained at water-saturated soil, the $i$ WUE increase in Arabidopsis and maize was approximately 100\% and 40\%, respectively, but water logging might be an issue at these high SWC levels. Between 30\% and 60\% SWC, the stomatal $\mathrm{CO}_{2}$ gradient of maize increased from 300 to $350 \mu \mathrm{mol} \mathrm{mol}^{-1}$, which corresponded to a $17 \%$ increase, whereas in Arabidopsis, the gradient was enhanced by $70 \%$, from 100 to $170 \mu \mathrm{mol} \mathrm{mol}^{-1}$.

To sum up, mild drought stress (30-60\% SWC) had a minor effect on $\mathrm{A}_{\mathrm{n}}, \mathrm{g}_{\mathrm{s}}$, and $i$ WUE in maize. However, in Arabidopsis, $\mathrm{g}_{\mathrm{s}}$ and $i$ WUE changed dynamically, while $\mathrm{A}_{\mathrm{n}}$ was little affected. A reduction in SWC from $35 \%$ to $25 \%$ led to a rapid decline of $\mathrm{A}_{n}$ in maize. 
These results are in accordance with data from $C_{3}$ and $C_{4}$ grass species $[77,78]$ but only partly meet the behavior expected for $C_{3}$ and $C_{4}$ plants based on a meta study [82] where decreases in $g_{s}$ and $A_{n}$ under mild drought stress were more pronounced in $C_{3}$ relative to $C_{4}$ species. Comparing the $A_{n}$ and $g_{s}$ curves of maize B73 and Arabidopsis Col-0 (Figure 2a,b and Figure 3a,b), a reduction in stomatal conductance led to an immediate reduction in assimilation rate $A_{n}$ for maize but not for Arabidopsis. However, not all $C_{3}$ plants show the same flat $A_{n} / g_{s}$ curve as Arabidopsis $[83,84]$ and therefore the data cannot be translated to $C_{3}$ crops in general. A previous study on maize lines found differences in $g_{s}$ without trade-offs in $A_{n}$ at well-watered conditions [85], and the author noted that $C_{i}$ values did not become low enough to limit $A_{n}$ as it might in high VPD conditions [85] or as it was observed here under drought.

Still, the limitations in improving WUE in maize B73 could be unique to this inbred line, and comparable data from other maize lines is needed before implications can be expanded to maize in general. Additionally, results from maize cannot represent $C_{4}$ photosynthesis in general because this pathway evolved independently in 19 angiosperm families [67]. However, other $C_{4}$ grass species have also shown a slight increase in $i$ WUE with progressive depletion of water followed by a steep decline under very severe drought conditions driven by a pronounced decline in $A_{n}[77,78]$. The loss of $A_{n}$ in the $\mathrm{C}_{4}$ grass species under drought could partly be attributed to stomatal limitations, while other limitations dominate, including photoinhibition, limitations of $\mathrm{CO}_{2}$ fixation due to desiccation, and decreases in $g_{m}[73,77]$.

It has also been shown that for subspecies of Alloteropsis semialata (R.Br.) Hitchc., $\mathrm{A}_{\mathrm{n}}$ is massively reduced in $C_{4}$ subspecies under drought in such a way that $C_{4}$ photosynthesis totally loses its advantage over photosynthesis of the $C_{3}$ subspecies [73]. This conclusion cannot be drawn from our experiments. However, the observation that $C_{3}$ plants become more water use efficient during mild and moderate drought while $\mathrm{C}_{4}$ plants show more stable WUE [86] is in accordance with our data on $i$ WUE.

The less potent improvement in WUE observed in maize under drought might be attributable to a limitation in increasing the $\mathrm{CO}_{2}$ gradient $\left(\mathrm{C}_{\mathrm{a}}-\mathrm{C}_{\mathrm{i}}\right)$ further. Maize, like other $\mathrm{C}_{4}$ species, possesses a $\mathrm{CO}_{2}$ concentrating mechanism utilizing precarboxylation of $\mathrm{CO}_{2}$ by $\mathrm{PEP}$ carboxylase, which results in $C_{i}$ values approximately half compared to $C_{3}$ species [87]. Such a mechanism results in advantages in $A_{n}$ and WUE under non- or mild-water-deficit conditions $[9,66,69,73,77,78]$. However, these advantages cannot be maintained when the drought gets severe, especially for maize and $\mathrm{C}_{4}$ grass species $[66,69,73,77,78,86]$, which is in agreement with our observation for maize B73 at SWC below $27 \%$. The differences can also translate to the field level, where maize has been found to be more sensitive to drought than wheat $\left(C_{3}\right)$, with yield reductions of $39.3 \%$ compared to $20.6 \%$, respectively, at approximately $40 \%$ water reduction [88]. Maize and sorghum are equally or even more sensitive to water stress than many $C_{3}$ plants $[69,73]$.

Our results show a potential to increase WUE in maize. The inbred lines displayed a broad variation in $W_{U E} E_{\text {plant }}$ under progressive drought, and $i$ WUE-measured under the same conditions for the least efficient line at whole plant level-still showed a moderate increase in $i$ WUE with declining SWC. However, the potential of WUE improvement is limited in this $\mathrm{C}_{4}$ plant compared to Arabidopsis. This limitation is caused by a very high $i$ WUE and low $C_{i}$ under well-watered conditions, which provides a minor degree of freedom for further lowering the $C_{i}$. The $C_{3}$ plant is more responsive concerning increases in $i$ WUE under mild water deficit compared to maize. Hence, screening $C_{3}$ plants for enhanced $i$ WUE in combination with efficient growth is a suitable approach to identify crops with improved $W U E_{\text {plant }}$. This approach is less promising for $\mathrm{C}_{4}$ plants. Establishing higher $C_{a}-C_{i}$ gradients in $C_{3}$ crops at a given soil water potential, e.g., by biotechnical engineering using ABA receptors, has the potential to increase $i W U E$ at the cost of minor reductions in $A_{n}$. Moderate reductions in $A_{n}$ do not necessarily influence yield. In barley, improvements in $i W U E$ and $W U E_{\text {plant }}$ have been associated with trade-offs in carbon assimilation but without deleterious effects on plant growth or seed yield [89]. 


\section{Conclusions}

Our results indicate that the improvement in $i$ WUE without trade-offs in carbon assimilation, as observed for tomato and Arabidopsis [15,63], is less promising for maize and possibly other $\mathrm{C}_{4}$ plants. The large $\mathrm{CO}_{2}$ gradient established by the $\mathrm{CO}_{2}$-concentrating mechanisms of $\mathrm{C}_{4}$ plants limits the potential for further increases in $i$ WUE compared to $C_{3}$ plants. However, our data show major differences in $W U E_{\text {plant }}$ for maize inbred lines and therefore potential for genetic improvement of this trait.

A recent meta-analysis on WUE revealed a tenfold bias in favor of $C_{3}$ plant studies compared to analyses on $C_{4}$ plants [86]. We therefore see an urgent need for more studies on $C_{4}$ crops to shed light on the mechanisms of WUE under water deficit in these important but drought-sensitive crops. Cereals like rice, maize, and wheat contribute largely to global food security [90]; therefore, breeding for and generating water-efficient and high yielding crops are an urgent task to meet future challenges.

Author Contributions: Conceptualization, E.G. and C.-C.S.; Methodology, Z.Y. and V.A.; Formal Analysis, Z.Y., V.A., S.B.; Investigation, Z.Y., V.A., S.B.; Resources, E.G. and C.-C.S.; Data Curation, Z.Y., V.A.; Writing-Original Draft Preparation, S.B.; Writing-Review \& Editing, Z.Y., V.A., E.G., C.-C.S.; Visualization, Z.Y., S.B.; Supervision, E.G., C.-C.S.; Project Administration, E.G., C.-C.S.; Funding Acquisition, E.G., C.-C.S.

Funding: This research was funded by the German Research Foundation (Deutsche Forschungsgemeinschaft; DFG) through the Sonderforschungsbereich 924 (SFB924): “Molecular mechanisms regulating yield and yield stability in plants" and the Bavarian State Ministry of the Environment and Consumer Protection within the project network BayKlimaFit (Project TGC01GCUFuE69779).

Acknowledgments: We thank Stefan Schwertfirm and Amalie Fiedler for technical assistance, Anne-Marie Stache for discussion of the statistical analysis, and Farhah Assaad for critical reading and constructive comments on the manuscript.

Conflicts of Interest: The authors declare no conflict of interest.

\section{References}

1. FAO. The Future of Food and Agriculture. Trends and Challenges; Food and Agriculture Organization of the United Nations: Rome, Italy, 2017.

2. Spinoni, J.; Naumann, G.; Carrao, H.; Barbosa, P.; Vogt, J. World drought frequency, duration, and severity for 1951-2010. Int. J. Climatol. 2014, 34, 2792-2804. [CrossRef]

3. Trenberth, K.E.; Dai, A.; van der Schrier, G.; Jones, P.D.; Barichivich, J.; Briffa, K.R.; Sheffield, J. Global warming and changes in drought. Nat. Clim. Chang. 2014, 4, 17-22. [CrossRef]

4. Morison, J.I.L.; Baker, N.R.; Mullineaux, P.M.; Davies, W.J. Improving water use in crop production. Philos. Trans. R. Soc. Lond. Ser. B Biol. Sci. 2008, 363, 639-658. [CrossRef] [PubMed]

5. Jobbágy, E.G.; Jackson, R.B. Groundwater use and salinization with grassland afforestation. Glob. Chang. Biol. 2004, 10, 1299-1312. [CrossRef]

6. Fahad, S.; Bajwa, A.A.; Nazir, U.; Anjum, S.A.; Farooq, A.; Zohaib, A.; Sadia, S.; Nasim, W.; Adkins, S.; Saud, S.; et al. Crop production under drought and heat stress: Plant responses and management options. Front. Plant Sci. 2017, 8, 1147. [CrossRef] [PubMed]

7. Spiertz, J.H.J.; Ewert, F. Crop production and resource use to meet the growing demand for food, feed and fuel: Opportunities and constraints. NJAS-Wagen. J. Life Sci. 2009, 56, 281-300. [CrossRef]

8. Rockström, J.; Lannerstad, M.; Falkenmark, M. Assessing the water challenge of a new green revolution in developing countries. Proc. Natl. Acad. Sci. USA 2007, 104, 6253-6260. [CrossRef] [PubMed]

9. Sadras, V.O.; Grassini, P.; Steduto, P. Status of water use efficiency of main crops. In The State of the World's Land and Water Resources for Food and Agriculture; F.A.O. Thematic Report No. 7; FAO: Rome, Italy, 2012.

10. Parry, M.A.J.; Flexas, J.; Medrano, H. Prospects for crop production under drought: Research priorities and future directions. Ann. Appl. Biol. 2005, 147, 211-226. [CrossRef]

11. Rizza, F.; Ghashghaie, J.; Meyer, S.; Matteu, L.; Mastrangelo, A.M.; Badeck, F.-W. Constitutive differences in water use efficiency between two durum wheat cultivars. Field Crops Res. 2012, 125, 49-60. [CrossRef]

12. Vadez, V.; Kholova, J.; Medina, S.; Kakkera, A.; Anderberg, H. Transpiration efficiency: New insights into an old story. J. Exp. Bot. 2014, 65, 6141-6153. [CrossRef] [PubMed] 
13. Ellsworth, P.Z.; Cousins, A.B. Carbon isotopes and water use efficiency in C4 plants. Curr. Opin. Plant Biol. 2016, 31, 155-161. [CrossRef] [PubMed]

14. Ryan, A.C.; Dodd, I.C.; Rothwell, S.A.; Jones, R.; Tardieu, F.; Draye, X.; Davies, W.J. Gravimetric phenotyping of whole plant transpiration responses to atmospheric vapour pressure deficit identifies genotypic variation in water use efficiency. Plant Sci. 2016, 251, 101-109. [CrossRef] [PubMed]

15. Yang, Z.; Liu, J.; Tischer, S.V.; Christmann, A.; Windisch, W.; Schnyder, H.; Grill, E. Leveraging abscisic acid receptors for efficient water use in Arabidopsis. Proc. Natl. Acad. Sci. USA 2016, 113, 6791-6796. [CrossRef] [PubMed]

16. Long, S.P.; Bernacchi, C.J. Gas exchange measurements, what can they tell us about the underlying limitations to photosynthesis? Procedures and sources of error. J. Exp. Bot. 2003, 54, 2393-2401. [CrossRef] [PubMed]

17. Gerosa, G.; Mereu, S.; Finco, A.; Marzuoli, R. Stomatal conductance modeling to estimate the evapotranspiration of natural and agricultural ecosystems. In Evapotranspiration: Remote Sensing and Modeling; Irmak, A., Ed.; InTech: Rijeka, Croatia, 2011; pp. 403-420.

18. Turner, N.C.; Schulze, E.-D.; Gollan, T. The responses of stomata and leaf gas exchange to vapour pressure deficits and soil water content: I. Species comparisons at high soil water contents. Oecologia 1984, 63, 338-342. [CrossRef] [PubMed]

19. Medrano, H.; Tomás, M.; Martorell, S.; Flexas, J.; Hernández, E.; Rosselló, J.; Pou, A.; Escalona, J.-M.; Bota, J. From leaf to whole-plant water use efficiency (WUE) in complex canopies: Limitations of leaf WUE as a selection target. Crop J. 2015, 3, 220-228. [CrossRef]

20. Farquhar, G.D.; Ehleringer, J.R.; Hubick, K.T. Carbon Isotope Discrimination and Photosynthesis. Annu. Rev. Plant Physiol. Plant Mol. Biol. 1989, 40, 503-537. [CrossRef]

21. Farquhar, G.D.; Richards, R.A. Isotopic composition of plant carbon correlates with water-use efficiency of wheat genotypes. Aust. J. Plant Physiol. 1984, 11, 539. [CrossRef]

22. Zhang, C.-Z.; Zhang, J.-B.; Zhao, B.-Z.; Zhang, H.; Huang, P. Stable isotope studies of crop carbon and water relations: A review. Agric. Sci. China 2009, 8, 578-590. [CrossRef]

23. Rebetzke, G.J.; Condon, A.G.; Richards, R.A.; Farquhar, G.D. Selection for reduced carbon isotope discrimination increases aerial biomass and grain yield of rainfed bread wheat. Crop Sci. 2002, 42, 739. [CrossRef]

24. Masle, J.; Gilmore, S.R.; Farquhar, G.D. The ERECTA gene regulates plant transpiration efficiency in Arabidopsis. Nature 2005, 436, 866-870. [CrossRef] [PubMed]

25. Sheshshayee, M.S.; Bindumadhava, H.; Ramesh, R.; Prasad, T.G.; Lakshminarayana, M.R.; Udayakumar, M. Oxygen isotope enrichment $(\Delta 18 \mathrm{O})$ as a measure of time-averaged transpiration rate. J. Exp. Bot. 2005, 56, 3033-3039. [CrossRef] [PubMed]

26. Barbour, M.M.; Farquhar, G.D. Relative humidity- and ABA-induced variation in carbon and oxygen isotope ratios of cotton leaves. Plant Cell Environ. 2000, 23, 473-485. [CrossRef]

27. Barbour, M.M.; Schurr, U.; Henry, B.K.; Wong, S.C.; Farquhar, G.D. Variation in the oxygen isotope ratio of phloem sap sucrose from castor bean. Evidence in support of the Péclet effect. Plant Physiol. 2000, 123, 671-680. [CrossRef] [PubMed]

28. Scheidegger, Y.; Saurer, M.; Bahn, M.; Siegwolf, R. Linking stable oxygen and carbon isotopes with stomatal conductance and photosynthetic capacity: A conceptual model. Oecologia 2000, 125, 350-357. [CrossRef] [PubMed]

29. Farquhar, G.D.; Lloyd, J. Carbon and oxygen isotope effects in the exchange of carbon dioxide between terrestrial plants and the atmosphere. In Stable Isotopes and Plant Carbon-Water Relations; Ehleringer, J.R., Hall, A.E., Farquhar, G.D., Eds.; Elsevier Science: Burlington, NJ, USA, 1993; pp. 47-70.

30. Battipaglia, G.; Saurer, M.; Cherubini, P.; Calfapietra, C.; McCarthy, H.R.; Norby, R.J.; Cotrufo, F.M. Elevated $\mathrm{CO}_{2}$ increases tree-level intrinsic water use efficiency: Insights from carbon and oxygen isotope analyses in tree rings across three forest FACE sites. New Phytol. 2013, 197, 544-554. [CrossRef] [PubMed]

31. Werner, C.; Schnyder, H.; Cuntz, M.; Keitel, C.; Zeeman, M.J.; Dawson, T.E.; Badeck, F.-W.; Brugnoli, E.; Ghashghaie, J.; Grams, T.E.E.; et al. Progress and challenges in using stable isotopes to trace plant carbon and water relations across scales. Biogeosciences 2012, 9, 3083-3111. [CrossRef]

32. Von Caemmerer, S.; Ghannoum, O.; Pengelly, J.J.L.; Cousins, A.B. Carbon isotope discrimination as a tool to explore C4 photosynthesis. J. Exp. Bot. 2014, 65, 3459-3470. [CrossRef] [PubMed] 
33. Lopes, M.S.; Araus, J.L.; van Heerden, P.D.R.; Foyer, C.H. Enhancing drought tolerance in C4 crops. J. Exp. Bot. 2011, 62, 3135-3153. [CrossRef] [PubMed]

34. Tardieu, F. Any trait or trait-related allele can confer drought tolerance: Just design the right drought scenario. J. Exp. Bot. 2012, 63, 25-31. [CrossRef] [PubMed]

35. Tardieu, F.; Parent, B.; Caldeira, C.F.; Welcker, C. Genetic and physiological controls of growth under water deficit. Plant Physiol. 2014, 164, 1628-1635. [CrossRef] [PubMed]

36. Tardieu, F.; Simonneau, T.; Muller, B. The physiological basis of drought tolerance in crop plants: A Scenario-Dependent Probabilistic Approach. Annu. Rev. Plant Biol. 2018, 69, 733-759. [CrossRef] [PubMed]

37. van Oosterom, E.J.; Yang, Z.; Zhang, F.; Deifel, K.S.; Cooper, M.; Messina, C.D.; Hammer, G.L. Hybrid variation for root system efficiency in maize: Potential links to drought adaptation. Funct. Plant Biol. 2016, 43, 502. [CrossRef]

38. Williams, M.; Woodward, F.I.; Baldocchi, D.D.; Ellsworth, D. $\mathrm{CO}_{2}$ capture from the leaf to the landscape. In Photosynthetic Adaptation: Chloroplast to Landscape; Smith, W.K., Vogelmann, T.C., Critchley, C., Eds.; Springer: Berlin, Germany, 2004; pp. 133-168.

39. Flexas, J.; Diaz-Espejo, A.; Galmés, J.; Kaldenhoff, R.; Medrano, H.; Ribas-Carbo, M. Rapid variations of mesophyll conductance in response to changes in $\mathrm{CO}_{2}$ concentration around leaves. Plant Cell Environ. 2007, 30, 1284-1298. [CrossRef] [PubMed]

40. Medrano, H. Regulation of photosynthesis of C3 plants in response to progressive drought: Stomatal conductance as a reference parameter. Ann. Bot. 2002, 89, 895-905. [CrossRef] [PubMed]

41. Flexas, J.; Díaz-Espejo, A.; Conesa, M.A.; Coopman, R.E.; Douthe, C.; Gago, J.; Gallé, A.; Galmés, J.; Medrano, H.; Ribas-Carbo, M.; et al. Mesophyll conductance to $\mathrm{CO}_{2}$ and Rubisco as targets for improving intrinsic water use efficiency in C3 plants. Plant Cell Environ. 2016, 39, 965-982. [CrossRef] [PubMed]

42. Monneveux, P.; Rekika, D.; Acevedo, E.; Merah, O. Effect of drought on leaf gas exchange, carbon isotope discrimination, transpiration efficiency and productivity in field grown durum wheat genotypes. Plant Sci. 2006, 170, 867-872. [CrossRef]

43. Urban, J.; Ingwers, M.W.; McGuire, M.A.; Teskey, R.O. Increase in leaf temperature opens stomata and decouples net photosynthesis from stomatal conductance in Pinus taeda and Populus deltoides x nigra. J. Exp. Bot. 2017, 68, 1757-1767. [CrossRef] [PubMed]

44. Flexas, J.; Bota, J.; Loreto, F.; Cornic, G.; Sharkey, T.D. Diffusive and metabolic limitations to photosynthesis under drought and salinity in C3 plants. Plant Biol. 2004, 6, 269-279. [CrossRef] [PubMed]

45. Hassiotou, F.; Ludwig, M.; Renton, M.; Veneklaas, E.J.; Evans, J.R. Influence of leaf dry mass per area, $\mathrm{CO}_{2}$, and irradiance on mesophyll conductance in sclerophylls. J. Exp. Bot. 2009, 60, 2303-2314. [CrossRef] [PubMed]

46. Flexas, J.; Barbour, M.M.; Brendel, O.; Cabrera, H.M.; Carriquí, M.; Díaz-Espejo, A.; Douthe, C.; Dreyer, E.; Ferrio, J.P.; Gago, J.; et al. Mesophyll diffusion conductance to $\mathrm{CO}_{2}$ : An unappreciated central player in photosynthesis. Plant Sci. 2012, 193-194, 70-84. [CrossRef] [PubMed]

47. Farquhar, G.D.; von Caemmerer, S.; Berry, J.A. A biochemical model of photosynthetic $\mathrm{CO}_{2}$ assimilation in leaves of C3 species. Planta 1980, 149, 78-90. [CrossRef] [PubMed]

48. Sharkey, T.D. Estimating the rate of photorespiration in leaves. Physiol. Plant 1988, 73, 147-152. [CrossRef]

49. Flexas, J. Genetic improvement of leaf photosynthesis and intrinsic water use efficiency in C3 plants: Why so much little success? Plant Sci. 2016, 251, 155-161. [CrossRef] [PubMed]

50. Long, S.P.; Zhu, X.-G.; Naidu, S.L.; Ort, D.R. Can improvement in photosynthesis increase crop yields? Plant Cell Environ. 2006, 29, 315-330. [CrossRef] [PubMed]

51. Parry, M.A.J.; Reynolds, M.; Salvucci, M.E.; Raines, C.; Andralojc, P.J.; Zhu, X.-G.; Price, G.D.; Condon, A.G.; Furbank, R.T. Raising yield potential of wheat. II. Increasing photosynthetic capacity and efficiency. J. Exp. Bot. 2011, 62, 453-467. [CrossRef] [PubMed]

52. Johnson, M.P.; Davison, P.A.; Ruban, A.V.; Horton, P. The xanthophyll cycle pool size controls the kinetics of non-photochemical quenching in Arabidopsis thaliana. FEBS Lett. 2008, 582, 262-266. [CrossRef] [PubMed]

53. Flexas, J.; Bota, J.; Escalona, J.M.; Sampol, B.; Medrano, H. Effects of drought on photosynthesis in grapevines under field conditions: An evaluation of stomatal and mesophyll limitations. Funct. Plant Biol. 2002, $29,461$. [CrossRef] 
54. Perez-Martin, A.; Michelazzo, C.; Torres-Ruiz, J.M.; Flexas, J.; Fernández, J.E.; Sebastiani, L.; Diaz-Espejo, A. Regulation of photosynthesis and stomatal and mesophyll conductance under water stress and recovery in olive trees: Correlation with gene expression of carbonic anhydrase and aquaporins. J. Exp. Bot. 2014, 65, 3143-3156. [CrossRef] [PubMed]

55. Olsovska, K.; Kovar, M.; Brestic, M.; Zivcak, M.; Slamka, P.; Shao, H.B. Genotypically Identifying Wheat Mesophyll Conductance Regulation under Progressive Drought Stress. Front. Plant Sci. 2016, 7, 1111. [CrossRef] [PubMed]

56. Ouyang, W.; Struik, P.C.; Yin, X.; Yang, J. Stomatal conductance, mesophyll conductance, and transpiration efficiency in relation to leaf anatomy in rice and wheat genotypes under drought. J. Exp. Bot. 2017, 68, 5191-5205. [CrossRef] [PubMed]

57. Flexas, J.; Ribas-Carbó, M.; Bota, J.; Galmés, J.; Henkle, M.; Martínez-Cañellas, S.; Medrano, H. Decreased Rubisco activity during water stress is not induced by decreased relative water content but related to conditions of low stomatal conductance and chloroplast $\mathrm{CO}_{2}$ concentration. New Phytol. 2006, 172, 73-82. [CrossRef] [PubMed]

58. Galmés, J.; Medrano, H.; Flexas, J. Photosynthetic limitations in response to water stress and recovery in Mediterranean plants with different growth forms. New Phytol. 2007, 175, 81-93. [CrossRef] [PubMed]

59. Blum, A. Drought resistance, water-use efficiency, and yield potential-Are they compatible, dissonant, or mutually exclusive? Aust. J. Agric. Res. 2005, 56, 1159. [CrossRef]

60. Kenney, A.M.; McKay, J.K.; Richards, J.H.; Juenger, T.E. Direct and indirect selection on flowering time, water-use efficiency (WUE, $\delta(13) \mathrm{C}$ ), and WUE plasticity to drought in Arabidopsis thatiana. Ecol. Evolut. 2014, 4, 4505-4521. [CrossRef] [PubMed]

61. Blum, A. Effective use of water (EUW) and not water-use efficiency (WUE) is the target of crop yield improvement under drought stress. Field Crops Res. 2009, 112, 119-123. [CrossRef]

62. Franks, P.J.; Doheny-Adams, T.; Britton-Harper, Z.J.; Gray, J.E. Increasing water-use efficiency directly through genetic manipulation of stomatal density. New Phytol. 2015, 207, 188-195. [CrossRef] [PubMed]

63. Thompson, A.J.; Andrews, J.; Mulholland, B.J.; McKee, J.M.T.; Hilton, H.W.; Horridge, J.S.; Farquhar, G.D.; Smeeton, R.C.; Smillie, I.R.A.; Black, C.R.; et al. Overproduction of abscisic acid in tomato increases transpiration efficiency and root hydraulic conductivity and influences leaf expansion. Plant Physiol. 2007, 143, 1905-1917. [CrossRef] [PubMed]

64. Yoo, C.Y.; Pence, H.E.; Jin, J.B.; Miura, K.; Gosney, M.J.; Hasegawa, P.M.; Mickelbart, M.V. The Arabidopsis GTL1 transcription factor regulates water use efficiency and drought tolerance by modulating stomatal density via transrepression of SDD1. Plant Cell 2010, 22, 4128-4141. [CrossRef] [PubMed]

65. Li, Y.; Xu, J.; Haq, N.U.; Zhang, H.; Zhu, X.-G. Was low $\mathrm{CO}_{2}$ a driving force of C4 evolution: Arabidopsis responses to long-term low $\mathrm{CO}_{2}$ stress. J. Exp. Bot. 2014, 65, 3657-3667. [CrossRef] [PubMed]

66. Long, S.P. Environmental responses. In $C_{4}$ Plant Biology; Sage, R.F., Monson, R.K., Eds.; Academic Press: San Diego, CA, USA, 1999; pp. 215-242.

67. Sage, R.F. The evolution of C4 photosynthesis. New Phytol. 2004, 161, 341-370. [CrossRef]

68. Downes, R.W. Differences in transpiration rates between tropical and temperate grasses under controlled conditions. Planta 1969, 88, 261-273. [CrossRef] [PubMed]

69. Ghannoum, O. C4 photosynthesis and water stress. Ann. Bot. 2009, 103, 635-644. [CrossRef] [PubMed]

70. Dai, Z.; Ku, M.; Edwards, G.E. C4 Photosynthesis: The $\mathrm{CO}_{2}$-concentrating mechanism and photorespiration. Plant Physiol. 1993, 103, 83-90. [CrossRef] [PubMed]

71. Wong, S.C.; Cowan, I.R.; Farquhar, G.D. Stomatal conductance correlates with photosynthetic capacity. Nature 1979, 282, 424-426. [CrossRef]

72. Leakey, A.D.B.; Uribelarrea, M.; Ainsworth, E.A.; Naidu, S.L.; Rogers, A.; Ort, D.R.; Long, S.P. Photosynthesis, productivity, and yield of maize are not affected by open-air elevation of $\mathrm{CO}_{2}$ concentration in the absence of drought. Plant Physiol. 2006, 140, 779-790. [CrossRef] [PubMed]

73. Ripley, B.S.; Gilbert, M.E.; Ibrahim, D.G.; Osborne, C.P. Drought constraints on C4 photosynthesis: Stomatal and metabolic limitations in C3 and C4 subspecies of Alloteropsis semialata. J. Exp. Bot. 2007, 58, 1351-1363. [CrossRef] [PubMed]

74. Chen, J.; Xu, W.; Velten, J.; Xin, Z.; Stout, J. Characterization of maize inbred lines for drought and heat tolerance. J. Soil Water Conserv. 2012, 67, 354-364. [CrossRef] 
75. Gresset, S.; Westermeier, P.; Rademacher, S.; Ouzunova, M.; Presterl, T.; Westhoff, P.; Schön, C.-C. Stable carbon isotope discrimination is under genetic control in the $\mathrm{C} 4$ species maize with several genomic regions influencing trait expression. Plant Physiol. 2014, 164, 131-143. [CrossRef] [PubMed]

76. Aslam, M.; Tahir, M.H.N. Morpho-physiological response of maize inbred lines under drought environment. Asian J. Plant Sci. 2003, 2, 952-954. [CrossRef]

77. Ripley, B.S.; Frole, K.; Gilbert, M. Differences in drought sensitivities and photosynthetic limitations between co-occurring C3 and C4 (NADP-ME) Panicoid grasses. Ann. Bot. 2010, 105, 493-503. [CrossRef] [PubMed]

78. Taylor, S.H.; Ripley, B.S.; Woodward, F.I.; Osborne, C.P. Drought limitation of photosynthesis differs between $\mathrm{C}_{3}$ and $\mathrm{C}_{4}$ grass species in a comparative experiment. Plant Cell Environ. 2011, 34, 65-75. [CrossRef] [PubMed]

79. Ranney, T.G.; Bir, R.E.; Skroch, W.A. Comparative drought resistance among six species of birch (Betula): Influence of mild water stress on water relations and leaf gas exchange. Tree Physiol. 1991, 8, 351-360. [CrossRef]

80. Easlon, H.M.; Nemali, K.S.; Richards, J.H.; Hanson, D.T.; Juenger, T.E.; McKay, J.K. The physiological basis for genetic variation in water use efficiency and carbon isotope composition in Arabidopsis thaliana. Photosyn. Res. 2014, 119, 119-129. [CrossRef] [PubMed]

81. Des Marais, D.L.; Razzaque, S.; Hernandez, K.M.; Garvin, D.F.; Juenger, T.E. Quantitative trait loci associated with natural diversity in water-use efficiency and response to soil drying in Brachypodium distachyon. Plant Sci. 2016, 251, 2-11. [CrossRef] [PubMed]

82. Yan, W.; Zhong, Y.; Shangguan, Z. A meta-analysis of leaf gas exchange and water status responses to drought. Sci. Rep. 2016, 6, 20917. [CrossRef] [PubMed]

83. Flexas, J.; Niinemets, U.; Gallé, A.; Barbour, M.M.; Centritto, M.; Diaz-Espejo, A.; Douthe, C.; Galmés, J.; Ribas-Carbo, M.; Rodriguez, P.L.; et al. Diffusional conductances to $\mathrm{CO}_{2}$ as a target for increasing photosynthesis and photosynthetic water-use efficiency. Photosynth. Res. 2013, 117, 45-59. [CrossRef] [PubMed]

84. Hall, A.E.; Schulze, E.-D. Stomatal response to environment and a possible interrelation between stomatal effects on transpiration and $\mathrm{CO}_{2}$ assimilation. Plant Cell Environ. 1980, 3, 467-474. [CrossRef]

85. Bunce, J.A. Leaf transpiration efficiency of some drought-resistant maize lines. Crop Sci. 2010, 50, 1409. [CrossRef]

86. Zhang, J.; Jiang, H.; Song, X.; Jin, J.; Zhang, X. The responses of plant leaf $\mathrm{CO}_{2} / \mathrm{H}_{2} \mathrm{O}$ exchange and water use efficiency to drought: A meta-analysis. Sustainability 2018, 10, 551. [CrossRef]

87. Farquhar, G.D.; Hubick, K.T.; Condon, A.G.; Richards, R.A. Carbon isotope fractionation and plant water-use efficiency. In Stable Isotopes in Ecological Research; Billings, W.D., Golley, F., Lange, O.L., Olson, J.S., Remmert, H., Rundel, P.W., Ehleringer, J.R., Nagy, K.A., Eds.; Springer: New York, NY, USA, 1989; pp. 21-40.

88. Daryanto, S.; Wang, L.; Jacinthe, P.-A. Global synthesis of drought effects on maize and wheat production. PLOS ONE 2016, 11, e0156362. [CrossRef] [PubMed]

89. Hughes, J.; Hepworth, C.; Dutton, C.; Dunn, J.A.; Hunt, L.; Stephens, J.; Waugh, R.; Cameron, D.D.; Gray, J.E. Reducing stomatal density in barley improves drought tolerance without impacting on yield. Plant Physiol. 2017, 174, 776-787. [CrossRef] [PubMed]

90. FAO. FAO Statistical Yearbook 2013. World Food and Agriculture; FAO: Rome, Italy, 2013.

(C) 2018 by the authors. Licensee MDPI, Basel, Switzerland. This article is an open access article distributed under the terms and conditions of the Creative Commons Attribution (CC BY) license (http:/ / creativecommons.org/licenses/by/4.0/). 